\title{
Anaerobic Biodegradability of Dairy Wastewater Pretreated with Porcine Pancreas Lipase
}

\author{
Adriano Aguiar Mendes ${ }^{1}$, Ernandes Benedito Pereira ${ }^{2 *}$, Agenor Furigo Jr. $^{3}$ and Heizir \\ Ferreira de Castro ${ }^{4}$ \\ ${ }^{1}$ Universidade Federal de São João Del-Rei; Campus Sete Lagoas; Rodovia MG 424, km 47; MG - Brasil. \\ ${ }^{2}$ Universidade Federal de Alfenas; 37130-000; Alfenas - MG - Brasil. ${ }^{3}$ Universidade Federal de Santa Catarina; \\ C. P.: 476; 88040-900; Florianópolis - SC - Brasil. ${ }^{4}$ Escola de Engenharia de Lorena; Universidade de São Paulo; \\ C. P.: 116; 12602-810; Lorena - SP - Brasil
}

\begin{abstract}
Lipids-rich wastewater was partial hydrolyzed with porcine pancreas lipase and the efficiency of the enzymatic pretreatment was verified by the comparative biodegradability tests (crude and treated wastewater). Alternatively, simultaneous run was carried out in which hydrolysis and digestion was performed in the same reactor. Wastewater from dairy industries and low cost lipase preparation at two concentrations $\left(0.05\right.$ and $\left.0.5 \% w \cdot v^{-1}\right)$ were used. All the samples pretreated with enzyme showed a positive effect on organic matter removal (Chemical Oxygen DemandCOD) and formation of methane. The best results were obtained when hydrolysis and biodegradation were performed simultaneously, attaining high COD and color removal independent of the lipase concentration. The enzymatic treatment considerably improved the anaerobic operational conditions and the effluent quality (lower content of suspended solids and less turbidity). Thus, the use of enzymes such as lipase seemed to be a very promising alternative for treating the wastewaters having high fat and grease contents, such as those from the dairy industry.
\end{abstract}

Key words: Biodegradability, hydrolysis, lipases, lipids-rich wastewater and biogas

\section{INTRODUCTION}

Lipids, characterized by the oils, fats, grease and long chain fatty acids (LCFA) are one of the major organic components of wastewaters from the food industries in addition to proteins and sugars (Demirel et al., 2005; Mendes et al., 2006a,b; Pereira et al., 2006). Important contributors to the lipids emission are wastewaters from the slaughterhouses, dairy industries and edible oil refineries. Lipids can cause severe environmental pollution as oils film formation on water surfaces, preventing the diffusion of oxygen from air into water and leading to the death of many forms of aquatic life. Aggregates formed by the oil droplets and other particles present in wastewater can also block water drainage lines (Demirel et al., 2005).

Treatment of lipids-rich wastewater could free several operational problems such as flotation of granular biomass (Mendes et al., 2005; Mendes et al., 2006 a,b), formation of fat lipids scum layers at the surface of the reactor, which do not digest (Masse et al., 2001) and the inhibiting toxicity effects of the intermediate compounds (LCFA) generated during the anaerobic digestion of the wastewater (Sousa et al., 2009). In addition, fats

\footnotetext{
* Author for correspondence: ernandes.pereira@unifal-mg.edu.br
} 
may solidify at lower temperatures causing operational damage such as clogging, and may develop unpleasant odors (Masse et al., 2001).

In order to cope with these negative effects on the water stream treatment, several strategies for removing these lipid residues at the head of the plant are proposed. Among these, the alternative of using specific enzymes (lipases) has gained more attention because of stringent environmental regulations, clean and friendly enzyme applications (Masse et al., 2001; Mendes et al., 2005; Mendes and Castro, 2005; Mendes et al., 2006a,b; Pereira et al., 2006). Lipases (triacylglycerol acylhydrolases, EC 3.1.1.3) are enzymes that catalyze the hydrolysis of triacylglycerols to glycerol and free fatty acids (FFA) at the water-lipid interface (Castro et al., 2004; Bruno et al., 2008). These enzymes showed potential applications in degrading the oil and fats in the wastewater generated by dairy industries and slaughterhouses (Masse et al., 2001; Mongkolthanaruk and Dharmsthiti, 2002; Mendes et al., 2005; Mendes e Castro, 2005; Mendes et al., 2006a,b; Pereira et al., 2006). The lipase application for lipid-rich wastewaters pretreatment has been proposed in the literature (Masse et al., 2001; Mongkolthanaruk and Dharmsthiti, 2002; Mendes et al., 2005; Mendes and Castro, 2005; Mendes et al., 2006a,b; Pereira et al., 2006). Slaughterhouses wastewater, containing between 2.5 and 3.0 g. $\mathrm{L}^{-1}$ of lipids, was pretreated with pancreatic PL-250 lipase during $4 \mathrm{~h}$ at room temperature (Masse et al., 2001). Pretreatment with PL-250 lipase reduced $60 \%$ average particle size and increased the free long-chain fatty acid concentration, indicating some solubilization of the pork fat particles in the slaughterhouse wastewater. Mongkolthanaruk and Dharmsthiti (2002) formulated a mixed bacterial culture composing Pseudomonas aeruginosa $\mathrm{LP}^{602}$, Acinetobacter calcoaceticus LP $^{009}$ (lipase producer) and Bacillus sp. $\mathrm{B}^{304}$ (protease and amylase producers) for treating kitchen's wastewater from public hospital. The BOD (Biochemical Oxygen Demand) and lipid contents were reduced from 3,500 and 20,000 mg. $\mathrm{L}^{-1}$, respectively, to lower than $20 \mathrm{mg} . \mathrm{L}^{-1}$ after 12 days under aerobic conditions. Results show the feasibility of the enzymatic treatment for wastewater with high fat contents, contributing to increase its anaerobic biodegradability (Mendes et al., 2006a,b).

In this work, the effect of using a wastewater treated with porcine pancreas lipase on the characteristics of sludge developed in an anaerobic digester was investigated by comparison with crude wastewater. Two enzyme concentrations were used to perform the hydrolysis of lipids present in the wastewater from dairy industries employing low cost lipase preparation (US\$ $0.12 . \mathrm{g}^{-1}$ solid). The selection of this lipase preparation was based on previous work carried out in our laboratory (Mendes and Castro, 2005). Moreover, it contained others hydrolytic enzymes as proteases and amylases that could be also important for the process, since wastewater from dairy industries contained lipids, proteins and starch compounds (Mendes et al., 2006 a,b).

\section{MATERIAL AND METHODS}

\section{Materials}

Commercial porcine pancreas lipase was purchased from Nuclear (São Paulo, Brazil). The lipase was a crude preparation with a lipolytic activity of 1,770 units. $\mathrm{mg}^{-1}$ solid (olive oil hydrolysis, $\mathrm{pH} 8.0$ at $37{ }^{\circ} \mathrm{C}$ ). Raw wastewater from dairy industry (Maringa Corporation, located at São Paulo-Brazil) collected before the flotation tank was used for all the experiments. Aliquots were stored in a freezer $\left(-4{ }^{\circ} \mathrm{C}\right)$ and characterized. Acclimated anaerobic sludge from an up flow anaerobic sludge blanket (UASB) treating the dairy industry wastewaters $\left(3.27 \mathrm{gVSS} . \mathrm{L}^{-1}\right.$ and $4.27 \mathrm{gTSS}^{-1} \mathrm{~L}^{-1}$ ) was used as inoculum for the biodegradation runs. All the chemical reagents were of analytical grade.
\end{abstract}

\section{Enzymatic hydrolysis}

Hydrolysis reactions were carried out in $350 \mathrm{~mL}$ steel flasks containing $250 \mathrm{~g}$ of crude wastewater. The wastewater $\mathrm{pH}$ was adjusted to 8.0 with $1 \mathrm{M}$ $\mathrm{NaOH}$ solution, followed by the addition of the

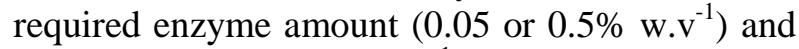
calcium ions $\left(0.1 \%\right.$ w. $\left.\mathrm{v}^{-1}\right)$ as additive for the lipase activity. The contents were agitated with a mechanical stirrer at a constant speed of $200 \mathrm{rpm}$. Reactions were carried out at $37{ }^{\circ} \mathrm{C}$ under atmospheric pressure for no longer than $4 \mathrm{~h}$ as already reported (Mendes et al., 2006a). At intervals, a small sample ( $2 \mathrm{~g}$ ) was removed from the reactor through a syringe, weighed and transferred to $100 \mathrm{~mL}$ conical flask. Fifty milliliters of a 50:50 $\mathrm{v} \cdot \mathrm{v}^{-1}$ mixture of acetone in 
ethanol were added to the sample and the mixture was titrated with standard $0.02 \mathrm{M}$ potassium hydroxide $(\mathrm{KOH})$ solution using phenolphthalein as indicator. At the end of reaction, the content of the hydrolyzed wastewater was heated at $60{ }^{\circ} \mathrm{C}$ for $10 \mathrm{~min}$ to denature the enzyme. Free fatty acids, protein and glycerol concentrations were determined. The percentage hydrolysis was calculated on the basis of glycerol formed during the hydrolysis reaction.

\section{Biodegradability assay tests}

Anaerobic biodegradability batch assays were performed in $500 \mathrm{~mL}$ closed glass flasks with a working volume of $250 \mathrm{~mL}$ of wastewater samples (crude and hydrolyzed) according to Mendes et al. (2006a). A plastic tube connected the vial to a 500 $\mathrm{mL}$ inverted flask (Duran ${ }^{\circledR}$ flasks) containing an alkaline solution $\left(0.5 \%\right.$ w. $\left.\mathrm{v}^{-1} \mathrm{NaOH}\right)$ allowed methane production to be measured by the displacement of the liquid. Anaerobic sludge (50 $\mathrm{mL}$ ) was transferred to the flasks containing enzymatically pretreated wastewater with low and high lipase concentrations (samples codified as $\mathrm{W} 1$ and W2). The tests were carried out in duplicate for a minimum period of 15 days and gently agitated (100 rpm). Before being closed, the bottles were flushed with nitrogen gas $\left(\mathrm{N}_{2}\right)$ to remove air in the flask head prior to incubation; the temperature was maintained at $35 \pm 1^{\circ} \mathrm{C}$. Control assays were also carried out to evaluate the biodegradability of the crude wastewater (C) and wastewater samples containing lipase at different concentrations ( 0.05 and $0.5 \%), \mathrm{C} 1$ and $\mathrm{C} 2$, respectively. For these control assays $(\mathrm{C} 1$ and $\mathrm{C} 2$ ) the hydrolysis and biodigestion steps were carried out simultaneously. Free fatty acids, protein and reducing sugars were measured at the beginning and at the end of the process. At the end of the biodigestion tests, samples were centrifuged at $10,000 \mathrm{rpm}$ for $20 \mathrm{~min}$ for analysis. The effect of wastewater enzymatic pretreatment on the efficiency of anaerobic digestion was determined by biogas production and COD and color removal.

\section{Analytical Methods}

Lipids, free fatty acids (FFA) and Chemical Oxygen Demand (COD) were determined according to the procedures described in the Standard Methods of Water and Wastewater Examination (APHA, 1995). The acidity was quantified by titration, using a solution of $0.1 \mathrm{M}$ $\mathrm{NaOH}$, recording the volume necessary to neutralize the level of free fatty acids in one gram of sample and expressing the results as the percentage of free fatty acids. The saponification value was calculated from the fatty acids composition, which corresponded to milligrams of potassium hydroxide necessary to neutralize the free fatty acids liberated from the hydrolysis of $1 \mathrm{~g}$ of the sample and it was inversely proportional to the molecular weight of the fatty acids present in the triacylglycerol (Moretto and Fett, 1998). Fatty acids distribution in the lipids was assayed with gas chromatograph (Varian Model CG 3800) equipped with a flame ionization detector (FID) and split-split less injector (split ratio 1:100). A capillary CP SIL 88 column $(50 \mathrm{~m} \mathrm{X} 0.25 \mathrm{~mm} \mathrm{X}$ $0.39 \mathrm{~mm}$; Varian) and hydrogen as carrier gas (average linear velocity $30 \mathrm{~mL} \cdot \mathrm{min}^{-1}$ ) were used. Samples were previously metilated according to the methodology described by Metcalfe et al. (1966). The peaks of the respective fatty acids methyl esters (FAMEs) were identified using the standard FAMEs (Sigma). Protein was determined by Lowry et al. (1951), while total reducing sugars were determined using 3,5 Dinitrosalicylic acid reagent (DNS) method (Miller, 1959). Glycerol was determined according to the methodology proposed by Coks and Van Rede (1966). The color was determined according to the CPPA standard method (CPPA, 1974), using the centrifuged samples with $\mathrm{pH}$ previously adjusted to 7.6 by the addition of $2 \mathrm{M} \mathrm{NaOH}$. The clear supernatant was used for reading the absorbance at $465 \mathrm{~nm}$ against distilled water. Absorbance values were transformed into color units $(\mathrm{CU})$ according to the equation 1 :

$\mathrm{CU}=\frac{500 \cdot A_{2}}{A_{1}}$

Where: $A_{1}$ is the absorbance of $500 \mathrm{CU}$ platinumcobalt standard solution $\left(A_{465}=0.132\right)$ and $A_{2}$ is the absorbance of the wastewater sample.

\section{RESULTS AND DISCUSSION}

\section{Characterization of dairy wastewater}

The characteristics of the dairy wastewater mean values are given in Table 1. The levels for proteins, reducing sugars and COD were lower than the values reported in the literature (Lyberatos et al., 1997; Demirel et al., 2005), but lipids concentration $\left(3,100 \mathrm{mg} . \mathrm{L}^{-1}\right)$ was about five times higher than the level normally found in dairy 
wastewater. Concerning the fatty acids distribution in the lipids, the crude wastewater contained the following concentrations $\left(\% \mathrm{w} . \mathrm{w}^{-1}\right)$ : capric $(2.4 \%)$, lauric $(3.2 \%)$, myristic (13.9\%), palmitic (39.2\%), stearic $(16.8 \%)$ and oleic $(21.2 \%)$.

\section{Enzymatic hydrolysis of wastewater}

Table 2 shows the composition of the hydrolyzed wastewater samples, using two lipase concentrations $(0.05$ and $0.5 \%)$ after $4 \mathrm{~h}$ incubation. As expected, increasing the amount of enzyme increased the free fatty acids (FFA) levels from 18.0 to $96.6 \mathrm{mM}$, corresponding to 8.5 and $27.7 \%$ of lipids hydrolysis degree, respectively. An increase in the protein hydrolysis degree was also detected from 7.9 to $28.0 \%$. The protein hydrolysis was due to the presence of proteases in the lipase preparation used in this work. The main compounds obtained in the protein hydrolysis are peptides and amino acids (Perle et al., 1995).

Table 1 - Characteristics of the dairy wastewater used in this study

\begin{tabular}{|c|c|}
\hline Parameter & Value \\
\hline $\mathrm{pH}$ & $5.38 \pm 0.62$ \\
\hline Total solids (mg. $\left.\mathrm{L}^{-1}\right)$ & $7.65 \pm 0.15$ \\
\hline Acidity $\left(\mathrm{mg} \mathrm{CaCO} 3 . \mathrm{L}^{-1}\right)$ & $0.75 \pm 0.07$ \\
\hline Value of saponification (mg KOH.g ${ }^{-1}$ ) & $174.0 \pm 1.84$ \\
\hline Free fatty acids $(\%)$ & $0.37 \pm 0.03$ \\
\hline Lipids (mg. $\left.\mathrm{L}^{-1}\right)$ & $3,100 \pm 150$ \\
\hline $\mathrm{COD}\left(\mathrm{mg} \cdot \mathrm{L}^{-1}\right)$ & $18,175 \pm 317$ \\
\hline Proteins $\left(\mathrm{mg} . \mathrm{L}^{-1}\right)$ & $500 \pm 11$ \\
\hline Reducing sugars (mg. $\left.\mathrm{L}^{-1}\right)$ & $370 \pm 4$ \\
\hline Glycerol (g.L $\left.\mathrm{L}^{-1}\right)$ & $0.37 \pm 0.04$ \\
\hline Density $\left(\mathrm{g} . \mathrm{cm}^{-3}\right)$ & $1.00 \pm 0.01$ \\
\hline Color $(\mathrm{CU})^{*}$ & $13,777 \pm 1,257$ \\
\hline Temperature $\left({ }^{\circ} \mathrm{C}\right)$ & 28.5 \\
\hline Flow of discharge $\left(\mathrm{m}^{3}\right.$. day $\left.^{-1}\right)$ & 100 \\
\hline
\end{tabular}

* CU: Color Units

Table 2 - Composition of the dairy crude and pretreated wastewater with porcine pancreas lipase (PPL) at two concentrations before the biodigestion step.

\begin{tabular}{|c|c|c|c|c|c|}
\hline \multirow{2}{*}{$\begin{array}{l}\text { PPL } \\
\left(\% \mathrm{w}^{-1}\right)^{-1}\end{array}$} & \multirow[t]{2}{*}{ Run } & \multirow{2}{*}{$\begin{array}{c}\text { FFA } \\
(\mathbf{m M})\end{array}$} & \multirow{2}{*}{$\begin{array}{c}\text { Glycerol } \\
(\%)\end{array}$} & \multicolumn{2}{|c|}{ Hydrolysis (\%) } \\
\hline & & & & Lipids & Protein \\
\hline None & $\mathrm{C}$ & $10.8 \pm 1.5$ & $0.37 \pm 0.06$ & 0 & 0 \\
\hline 0.05 & W1 & $18.1 \pm 2.0$ & $0.41 \pm 0.03$ & 8.5 & 7.9 \\
\hline 0.5 & W2 & $96.6 \pm 10.3$ & $0.52 \pm 0.05$ & 27.7 & 28.0 \\
\hline
\end{tabular}

FFA: Free fatty acids,

C: Crude wastewater;

W1 and W2: 4h hydrolyzed samples.

\section{Biodegradability assay tests}

Results obtained in terms of reducing sugars, protein concentrations, organic matter (COD), free fatty acids, color and biogas volume (cumulative values) are shown in Table 3 for control assays (C, C1 and $\mathrm{C} 2)$ and enzymatically pretreated samples (W1 and W2). A slight higher residual sugar concentration was found in crude wastewater assay (C), whereas reducing sugar was almost entirely degraded in the other assays (W1, W2, C1 and C2). These results suggested that the anaerobic sludge biomass easier assimilated the reducing sugars contained in the hydrolyzed wastewaters than in the crude wastewaster. Concerning the protein levels, similar results were attained for all assays and protein degradation ranged from $87.9 \%$ (C) to $89.6 \%$ (W2). 
The biogas production from the crude wastewater $(209 \pm 27 \mathrm{~mL})$ was lower than all hydrolyzed wastewater samples, including the control assays $\mathrm{C} 1$ and $\mathrm{C} 2$. Maximum biogas production $(403 \pm 40 \mathrm{~mL})$ was obtained for the wastewater pretreated with high lipase concentration $\left(0.5 \% \mathrm{w} \cdot \mathrm{v}^{-1}\right)$, almost twice higher than the crude wastewater. Similar values for biogas formation $(\approx 350 \mathrm{~mL})$ were reached for the pretreated wastewater with low enzyme concentration $\left(0.05 \% \mathrm{w} \cdot \mathrm{v}^{-1}\right)$ and both control assays, in which hydrolysis and biodegradability were carried out simultaneously. In addition, the simultaneous procedure resulted in a slight increase in the COD removal, with a maximum value attained for $\mathrm{C} 2$ assay (76.4\%), twice higher than for crude wastewater $(38.2 \%)$.

The color reduction was also influenced by the enzymatic pretreatment. For the crude wastewater (C) about $13.9 \%$ of color removal was detected. The highest value was obtained for simultaneously hydrolyzed and biodegraded sample using low enzyme amount $(82.7 \%-\mathrm{C} 1)$. This value was around four times higher than $\mathrm{C}$ (crude wastewater). Samples pretreated enzimatically, independent of the enzyme amount, removed color similarly, between 71.1 and $76.4 \%$ as shown in Table 3 .

The COD removal was effective due to the biodegradation of lipids and their products (glycerol and fatty acids). The lipid removal also enhanced the biogas formation, probably, because the enzymatically pretreated samples were not subjected to sludge flotation, whereas for the crude wastewater assay, this phenomenon was observed.

The adhesion of non-biodegraded lipids on the cells surface of the biomass made difficult the liberation of the formed gas, like $\mathrm{CO}_{2}$ and $\mathrm{CH}_{4}$, leading to sludge flotation (Mendes et al., 2006a).

Table 3 - Composition of the dairy wastewater biodegraded in batch reactors running with crude and enzymatically pretreated samples $\left(35^{\circ} \mathrm{C}, 15\right.$ days, agitation $\left.100 \mathrm{rpm}\right)$.

\begin{tabular}{ccccccc}
\hline $\begin{array}{c}\text { PPL } \\
(\% \text { w/v })\end{array}$ & Run & \multicolumn{4}{c}{ Removal (\%) } & Biogas \\
\cline { 3 - 6 }$(\mathbf{m L})$ & Reducing Sugars & COD & Protein & Color & $209 \pm 27$ \\
\hline None & C & $89.9 \pm 1.7$ & $38.2 \pm 2.7$ & $87.9 \pm 0.1$ & $13.9 \pm 1.3$ & $346 \pm 30$ \\
0.05 & $\mathrm{C} 1$ & $98.0 \pm 1.8$ & $62.8 \pm 4.3$ & $88.2 \pm 0.2$ & $82.7 \pm 0.8$ & $359 \pm 32$ \\
& $\mathrm{~W} 1$ & $97.6 \pm 1.9$ & $58.1 \pm 4.1$ & $86.4 \pm 0.1$ & $71.1 \pm 0.7$ & $354 \pm 34$ \\
0.5 & $\mathrm{C} 2$ & $97.7 \pm 0.4$ & $76.4 \pm 4.2$ & $88.8 \pm 0.3$ & $68.7 \pm 0.4$ & $403 \pm 40$ \\
\hline
\end{tabular}

C: Crude wastewater; C1: Control 1 and C2: Control 2.

$\mathrm{W} 1$ and W2: 4 h hydrolyzed samples

\section{CONCLUSIONS}

In this work, a cheap commercially available lipase preparation from porcine pancreas lipase was used for decreasing lipids and organic contents in dairy wastewater. The biodigestion tests carried out with hydrolyzed samples showed higher reaction rate in relation to crude wastewater assay, which was confirmed by the increased levels of biogas production and higher COD and color removal. The best results were obtained when the hydrolysis and biodigestion were performed simultaneously, attaining high COD and color removal, and independent of the lipase concentrations. This result showed that the hydrolysis and biodigestion could be carried out simultaneously, preferentially using low enzyme concentration $\left(0.05 \%\right.$ W.v $\left.\mathrm{v}^{-1}\right)$ which could reduce both the cost and process duration.

\section{ACKNOWLEDGMENTS}

The authors gratefully acknowledge the financial assistance of $\mathrm{CNPq}$ (Conselho Nacional de Desenvolvimento Científico- Programa CT-Hidro) and FAPESP, Brazil. 


\section{RESUMO}

O presente trabalho teve como objetivo o prétratamento de efluente da indústria de laticínios na hidrólise de lipídeos, empregando lipase de fonte de células animais de baixo custo disponível comercialmente (pâncreas de porco) na formação de gás metano por biodegradabilidade anaeróbia empregando diferentes concentrações de lipase $\left(0,05\right.$ e $0,5 \%$ w. $\left.\mathrm{v}^{-1}\right)$. A utilização de lipase no prétratamento do efluente acelerou a hidrólise de lipídeos e, conseqüentemente, auxiliou o tratamento biológico resultando na redução da matéria orgânica em termos de Demanda Química de Oxigênio (DQO), cor e sólidos em suspensão como lipídeos. Os melhores resultados em termos de remoção de DQO e cor foram obtidos quando a hidrólise e biodigestão foram realizadas simultaneamente, independente da concentração de lipase empregada. Estes resultados mostram que a hidrólise e biodigestão podem ser realizadas simultaneamente empregando baixa concentração de lipase $\left(0,05 \%\right.$ w.v $\left.{ }^{-1}\right)$, contribuindo para a redução de custo e tempo no processo de biodegradação aneróbia.

\section{REFERENCES}

APHA, AWWA, WPCF, 1995, In- Standard Methods for Examination of Water and Wastewater, $19^{\text {th }}$ ed. New York, United States of America.

Bruno, L. M.; Lima Filho, J. L. and Castro, H. F. (2008), Comparative performance of microbial lipases immobilized on magnetic polysiloxane polyvinyl alcohol particles. Braz. Arch. Biol. Technol., 51, 889-896.

Castro, H. F.; Mendes, A. A.; Santos, J. C. and Aguiar, C. L. (2004), Modificação de óleos e gorduras por biotransformação. Quim. Nova, 27, 146-156.

Coks, L. V. and Van Rede, C. (1966), In- Laboratory handbook for oils and fats analysis. $1^{\text {st }}$ ed. Academy Press, London, England.

CPPA, 1974. Technical Section Standard Methods H5P. Demirel, B.; Yenigun, O. and Onay, T. T. (2005), Anaerobic treatment of dairy wastewaters: A review, Process Biochem., 40, 2583-2595.

Lowry, O. H., Rosebrough, N. J., Farr, A. L. and Randall, R. J. (1951), Protein measurement with the Folin phenol reagent. J. Biol. Chem., 193, 265-275.
Lyberatos, G., Gavala, H. N. and Stamatelatou, A. (1997), An integrated approach for management of agricultural industries wastewater. Non. Anal., Theory, Meth. Appl., 30, 2341-2351.

Masse, L.; Kennedy, K. J. and Chou, S. (2001), Testing of alkaline and enzymatic pretreatment for fat particles in slaughterhouses wastewater. Bioresour. Technol., 77, 145-155.

Miller, G. L. (1959), Use of dinitrosalicylic acid reagent for determination of reducing sugar. Anal. Chem., 31, 426.

Mendes, A. A.; de Castro, H. F.; Pereira, E. B. and Furigo Jr., A. (2005), Aplicação de lipases no tratamento de águas residuárias com elevado teor de lipídeos. Quim. Nova, 28, 296-305.

Mendes, A. A. and de Castro, H. F. (2005), Effect on the enzymatic hydrolysis of lipids from dairy wastewater by replacing gum arabic emulsifier for sodium chloride. Braz. Arch. Biol. Technol., 48, 135142.

Mendes, A. A.; Pereira, E. B. and Castro, H. F. (2006a), Effect of the enzymatic hydrolysis pretreatment of lipids-rich wastewater on the anaerobic biodigestion. Biochem. Eng. J., 32, 185-190.

Mendes, A. A.; Pereira, E. B. and de Castro, H. F. (2006b), Biodegradation of wastewater from dairy industries previously treated with lipases. Braz. J. Food Technol., 9, 143-149.

Metcalfe, L. D.; Schmitz, A. A. and Pelka, J. R. (1966), Rapid preparation of fatty acid esters from lipids for gas chromatographic analysis. Anal. Chem., 38, 514515.

Mongkolthanaruk, W. and Dharmsthiti, S., (2002), Biodegradation of lipid-rich wastewater by a mixed bacterial consortium. Int. Biotererior. Biodegrad., 50, 101-105.

Moretto, E. and Fett, R. (1998), In- Tecnologia de Óleos e Gorduras Vegetais na Indústria de Alimentos. Ed. UFSC, 150 p.

Pereira, E. B.; Furigo Jr., A.; de Castro, H. F. and Reginatto, V. S. (2006), Degradation of fat and grease in slaughterhouse wastewater by a commercial microbial lipase. Braz. Arch. Biol. Technol., 49, 2128.

Perle, M., Kimchie, S. and Shelef, G. (1995), Some biochemical aspects of the anaerobic degradation of dairy wastewater. Water Res., 29, 1549-1554.

Sousa, D. Z.; Smidt, H.; Alves, M. M. and Stams, A. J. M. (2009), Ecophysiology of syntrophic communities that degrade saturated and unsaturated long-chain fatty acids. FEMS Microbiol. Ecol., 68, 257-272. 